\title{
ANALISIS PERBANDINGAN PENERAPAN METHOD NET BASIC DAN GROSS UP TERHADAP BEBAN PAJAK PENGHASILAN BADAN (Studi Kasus Pada PT.HI)
}

\author{
Imar Halimah \\ Fakultas Ekonomi, Universitas Pamulang \\ dosen01082@gmail.com
}

\begin{abstract}
The purpose of this study was to analyze the comparison of the application of the Net Method method and the Gross-up Method in the calculation of Article 21 Income Tax and find out which method was the most efficient used to save how much the Corporate Income Tax Expense (PPh owed by the agency) PT. HI, in this case the data analyzed is in 2011,2012 and 2013.

Data collection methods used in this study are secondary data obtained through documentation and observation of data for three years, namely in 2011 to 2013.

The analytical method used in this study is descriptive analysis with a qualitative approach, namely research using documents or slowness, with data sources obtained from primary and secondary data, primary data is data obtained directly from the company, namely a general description of the company, data calculation of Income Tax Article 21 companies and profit and loss financial report data in 2011, 2012 and 2013. While secondary data is data processed by companies that are used as material for researchers.

The results of this study indicate that there are differences between the net basic method and gross up method in the calculation of Article 21 Income Tax where the higher income tax payable if using gross up method with the acquisition of the difference in 2011 amounting to Rp.15,236,870, -, in 2012 of Rp. .19,573,460, - and in 2013 amounting to Rp.21,116,470, - but in this case the most efficient method of calculating Income Tax Article 21 on the calculation of income tax is owed by the corporate body using the gross-up method because by using gross up PPh method Article 21 payable can be financed in fiscal financial statements (uncorrected), while the net basic method of Article 21 Income Tax payable is made a positive correction so that the corporate corporate income tax burden is greater than using gross up method, and the results of comparison of calculations performed, gross method up does produce efficiency against Corporate Income Tax where companies can save money $n$ income tax in 2011 amounted to Rp. 25,993,196, - in 2012 Rp. 34,605,170, and in 2013 as much as Rp. 37,654,003.
\end{abstract}

Keywords : net basic method, gross up method, Income Tax Expense

\section{PENDAHULUAN}

Perusahaan merupakan objek utama dalam bidang perpajakan, dimana perusahaan mempunyai kewajiban untuk membayar pajak, walaupun sebenarnya perusahaan tidak menginginkan adanya pembayaran pajak namun hal tersebut tidak dapat dihindari lagi bahwa pajak sudah merupakan bagian 
dari kewajiban Perusahaan, salah satu cara yang dapat dilakukan oleh perusahaan adalah meminimalkan beban pajak dengan melakukan perencanaan pajak. Seperti halnya PT. HI yang mempunyai kewajiban untuk membayar Pajak Penghasilan salah satunya adalah Pajak Penghasilan Badan. Selain membayar pajak penghasilan itu sendiri, perusahaan juga menghimbau agar karyawannya turut serta membayar pajak penghasilan dari penghasilan yang diterima maupun yang diperoleh karyawan tersebut yaitu gaji. Gaji merupakan wujud dari imbalan yang diberikan oleh perusahaan kepada karyawan yang telah memberikan tenaganya untuk melangsungkan kehidupan perusahaan. Gaji merupakan salah satu unsur penting bagi perusahaan karena jika gaji yang diberikan terlalu kecil maka kinerja karyawan tidak terlalu tinggi atau operasional perusahaan akan terganggu dengan adanya demo dari karyawan.

Pajak penghasilan yang dikenakan atas gaji adalah pajak penghasilan Pasal 21. Pajak Penghasilan Pasal 21 merupakan pajak yang dikenakan atas penghasilan berupa gaji, upah, honorarium, tunjangan dan pembayaran lain dengan nama apa pun yang diterima atau diperoleh Wajib Pajak orang pribadi dalam negeri sehubungan dengan pekerjaan/ jabatan, jasa dan kegiatan. PT. HI merupakan Pengusaha Kena Pajak yang telah dikukuhkan sebagai Pengusaha Kena Pajak, perusahaan yang bergerak di dagang (Restoran) ini mempunyai tujuan mencapai laba yang optimum dengan meminimalkan beban perusahaan dan beban pajak Penghasilan Badan.

Dalam hal ini PT. HI menghitung Pajak Penghasilan atas gaji karyawan dengan menggunakan Net Basic method, net basic disini merupakan metode pemotongan pajak dimana perusahaan menanggung pajak karyawannya, hal demikian merupakan pengeluaran bukan merupakan biaya bagi perusahaan dan bukan merupakan penghasilan bagi karyawan. dimana Pajak Penghasilan Pasal 21 tersebut ditanggung oleh perusahaan, dan menjadikan beban perusahaan besar dengan laba minimal. tetapi salah satu upaya untuk menjalin kerja sama yang baik dengan karyawan adalah memberikan berbagai tunjangan bagi para karyawannya termasuk tunjangan pajak yang telah disepakati oleh perusahaan dan karyawan, maka dalam hal ini peneliti melakukan perencanaan pajak untuk 
perhitungan pajak penghasilan pasal 21 Atas penghasilan karyawannya tersebut dengan metode Gross Up, tentunya hal ini dilakukan untuk menguntungkan perusahaan dalam perhitungan Pajak Penghasilan Pasal 21. Metode gross up ini dicatat sebagai tunjangan pajak dimana hal ini bisa dijadikan sebagai beban perusahaan yang dapat dibebankan atau diperhitungkan dalam menghitung pajak penghasilan badan yaitu sebagai pengurang pendapatan. Walaupun mengurangi pendapatan perusahaan dan jumlah beban besar sehingga laba perusahaan kecil maka biaya pajak atau pajak yang harus dibayarkan oleh perusahaan kecil maka dalam hal ini peneliti melakukan analisis bagaimana sebenarnya cara perusahaan ini menghitung PPh Pasal 21 dan metode manakah yang dapat mempengaruhi beban pajak penghasilan badan secara signifikan.

\section{TELAAH LITERATUR DAN PENGEMBANGAN HIPOTESIS}

Method Net merupakan metode pemotongan pajak dimana perusahaan menanggung pajak karyawannya. Dalam hal demikian, pengeluaran tersebut bukan merupakan biaya bagi perusahaan dan bukan merupakan penghasilan bagi karyawan. Sebagaimana dimaksud dalam Kep. Dirjen Pajak No. 31/PJ./2008 Pasal 5 ayat (2) dan Pasal 8 ayat (I), Penghasilan yang dipotong PPh Pasal 21 dan/atau PPh Pasal 26 termasuk pula penerimaan dalam bentuk natura dan/atau kenikmatan lainnya dengan nama dan dalam bentuk apapun yang diberikan oleh bukan Wajib Pajak, Wajib Pajak yang dikenakan Pajak penghasilan yang bersifat final; atau Wajib Pajak yang dikenakan Pajak Penghasilan berdasarkan norma penghitungan khusus (deemed profit). Selanjutnya pada Pasal 8 ayat 2 menegaskan bahwa Pajak Penghasilan yang ditanggung oleh pemberi kerja, termasuk yang ditanggung oleh Pemerintah, merupakan penerimaan dalam bentuk kenikmatan.

Method Gross Up Merupakan Metode pemotongan pajak dimana perusahaan memberikan tunjangan pajak yang jumlahnya sama besar dengan jumlah pajak yang dipotong dari karyawan. 


\section{a. Kepasatian Umum metode gross up}

Per. Dirjen pajak No. 64/PJ/2009 Penetapan jumlah Pajak Penghasilan Ditanggung Pemerintah atas Penghasilan berupa Kompensasi Terminasi Dini Hak Eksklusif Telkom yang harus dibayarkan Pemerintah kepada Telkom merupakan Objek Pajak, yang dihitung dengan metode gross up. Lalu menurut Private ruling Surat Dirjen Pajak No. S. 1149/PJ.312/2004 tentang Pajak Penghasilan atas bunga (kupon) tetap Obligasi Negara Dalam Valas dengan metode gross up yang pengenaannya dengan melakukan gross up terhadap pembayaran bunga tersebut. Hingga saat ini tidak ada ketentuan yang mengatur konsistensi perhitungan $\mathrm{PPh}$ pasal 21 dengan metode gross up dimaksud padahal aplikasi metode ini sudah menjadi salah satu model dan opsi kebijakan perpajakan yang diterapkan di banyak perusahaan. Semua pihak, baik fiskus maupun wajib pajak telah meyakini dan bahkan banyak yang sudah hapal di luar kepala tentang prinsip taxability-deductibility yang dijabarkan dalam Pasal 4 ayat 1 (taxable income) dan Pasal 4 ayat 3 (nontaxable income) serta Pasal 6 ayat 1 (deductible expenses) dan Pasal 9 ayat 1 (nondeductible expenses). Dalam hubungan kerja antar perusahaan dengan karyawan, mekanisme prinsip tersebut berlaku, jika dikaryawan merupakan penghasilan (taxable income), maka di perusahaan boleh menjadi biaya. (deductible expense), atau sebaliknya jika dikaryawan merl upakan bukan penghasilan (nontaxable income), maka di perusahaan menjadi bukan biaya (non-deductible expense).

Semua penghasilan dengan nama dan dalam bentuk apapun yang sudah dikenakan pajak (bukan $\mathrm{PPh}$ final) dapat dibiayakan menjadi pengurang penghasilan dalam laporan keuangan fiskal atau SPT PPh Badan. Dalam pengertian penghasilan yang menjadi objek pajak penghasilan tersebut termasuk tunjangan. Jadi sebenarnya landasan hukum pemberian tunjangan pajak yang dalam perlakuan pajaknya diakui sebagai biaya deductible itu sudah jelas, secara eksplisit tertuang dalam Pasal 4 $\mathrm{UU} \mathrm{PPh}$, sesuai dengan makna prinsip taxability-deductibility. Artinya 
bilamana penghasilan (dari tunjangan pajak) karyawan tersebut sudah dipajaki dan disetorkan ke Kas Negara serta sudah dilaporkan dalam SPT PPh Pasal 21, maka bagi pemberi kerja atas pengeluaran (biaya tunjangan pajak) tersebut dapat dibiayakan menjadi pengurang penghasilan dalam laporan keuangan fiskal atau SPT PPh Badan. Tentu dengan catatan, transaksi tersebut didukung dengan adanya penjurnalan biaya tunjangan pajak didalam pembukuan wajib pajak serta juga tercantum dalam slip gaji karyawan.

\section{Perbedaan principal antara Net method dengan Gross-Up Met}

Perbedaan prinsipil antara Net Method dengan Gross-Up Method yaitu

1. Bahwa pada Metode Net besarnya PPh Pasal 21 yang ditanggung oleh perusahaan tersebut tidak dimasukkan sebagai tunjangan pajak di SPT PPh Pasal 21, sedangkan pada Metode gross up, besarnya tunjangan pajak Pasal 21 tersebut dimasukkan sebagai elemen penghasilan dari tunjangan pajak yang dicantumkan di SPT PPh Pasal 21.

2. Bahwa pada Metode Net, besarnya PPh Pasa1 21 yang ditanggung oleh Perusahaan tidak bisa dibiayakan (non deductible) sedangkan pada Metode gross up seluruh tunjangan pajaknya bisa dibiayakan (deductible).

\section{METODE PENELITIAN}

Metode yang digunakan penulis dalam menyusun penelitian ini dengan menggunakan metode analisis deskriptif kualitatif, dimana metode analisis deskriptif adalah metode yang bertujuan untuk mengumpulkan data dan informasi yang dapat menggambarkan keadaan objek penelitian dan menyederhanakannya untuk menjelaskan masalah dan pemecahannya agar dapat dibaca dan mudah dimengerti. Sedangankan kualitatif bertujuan untuk memperoleh gambaran dan pemahaman yang menyeluruh terhadap permasalahan yang akan diteliti. Pendekatan pada penelitian ini menggunakan permasalahan secara mendalam tentang suatu ketentuan. Pemahaman secara 
mendalam dalam skripsi ini didapatkan dengan cara mengulang kembali perhitungan pajak yang sudah dibayar, disetor dan dilapor dan kemudian membandingkannya dengan perhitungan pajak yang sudah dibayar, disetor dan dilapor yang sudah ditambahkan variabel lain, untuk mendapat biaya pajak yang minimum.

\section{HASIL PENELITIAN DAN PEMBAHASAN}

PT. HI merupakan salah satu Wajib Pajak Badan yang telah terdaftar pada Direktorat Jendaral Pajak, Kantor Pelayanan Pajak (KPP) Sunter sebagai Pusat dengan NPWP 02.238.270.9-048.000.

PT. HI adalah perusahaan yang bergerak di bidang perdagangan yaitu Restoran yang dikenal dengan nama Siam Square ini merupan restoran makanan cepat saji yang menyajikan khas Thailand yang berbasis di Jakarta Indonesia, Restoran yang memiliki konsep Thai Food Modern ini memiliki menu favorit diantaranya adalah Tom Yam Noodles Soup, Drunken Noodles dan Spicy Noodles, Squid Salted, dan sweet Casava untuk dessert. Sementara minuman favoritnya adalah Thai Ice Tea. Perusahaan ini didirikan di Indonesia dengan Akta Notaris Dr.Irwan Soeradjo SH, M.Si No. 70 tanggal 9 Juli 2002 dan telah disahkan oleh Menteri Keuangan.

\section{Penerapan method Net Basic dan Gross Up dalam perhitungan pajak penghasilan Psl. 21}

\section{a. Penerapan Method Net Basic}

Dibawah ini disajikan rekapitulasi Pajak Penghasilan Pasal 21 perusahaan, dimana pada tahun 2011 dengan jumlah karyawan 90 orang, pada tahun 2012 dengan jumlah karyawan 100 orang, dan untuk tahun 2013 ini meningkat dengan jumlah karyawan 110 orang, dengan ini mengenai perhitungan Pajak Penghasilan Pasal 21 yang dilakukan perusahaan dengan menggunakan metode net basic, peneliti melakukan perhitungan ulang dan dapat disimpulkan bahwa perusahaan telah melakukan perhitungan Pajak Penghasilan Pasal 21 tersebut telah sesuai dengan peraturan atau undang-undang yang berlaku mengenai 
PPh karyawan, sehingga tidak melakukan perubahan apapun terhadap data yang diperoleh, dimana tabel 1 menunjukan kesimpulan PPh terutang perusahaan selama tiga tahun:

Tabel 1

Jumlah PPh Pasal 21 terutang method Net

\begin{tabular}{|c|c|}
\hline Tahun & PPh Pasal 21 \\
\hline 2011 & Rp. 104.244.910 \\
\hline 2012 & Rp.135.398.720 \\
\hline 2013 & Rp.128.074.650 \\
\hline
\end{tabular}

Sumber : PT. HI

Dari rekap diatas tersebut di atas, karyawan PT.HI masih ada yang belum memiliki NPWP. Pada perhitungan pajak penghasilan karyawan bernama Maulana Yusuf yang tidak memiliki NPWP PPh terutangnya mengalami kenaikan 20\% dimana PPh terhutang lebih besar dari seharusnya. Dalam hal ini perusahaan telah melakukan pemotongan PPh kepada karyawan sesuai dengan peraturan perpajakan.

Berdasarkan penelitian dan informasi melalui bagian Pajak yang peneliti lakukan di PT. HI, diperoleh data penyetoran dan pelaporan Pajak Penghasilan Pasal 21 yang dilakukan PT. HI telah sesuai dengan peraturan perpajakan dimana penyetoran dilakukan perusahaan maksimal tanggal 10 pada bulan berikutnya, dan pelaporan paling maksimal pada tanggal 20 bulan berikutnya.

\section{b. Penerapan method Gross Up dalam perhitungan pajak penghasilan Pasal 21}

Pajak Penghasilan dengan metode gross up salah satu karyawan atas nama Nanti sebagaiman telah dilakukan perhitungan dengan menggunakan metode net yang telah diperoleh Penghasilan Kena Pajak (PKP) sebesar Rp.147.820.620 sebelum adanya tunjangan pajak, untuk mengetahui berapa tunjangan pajak dalam setahun maka menggunakan rumus tersebut diatas dengan rumus lapisan II yaitu: 
Tunjangan Pajak (Gross Up) Lapisan II:

$=(\mathrm{PKP}$ setahun $-47.500 .000 \times 15 / 85)+2.500 .000$

$=($ Rp.147.820.620 - 47.500.000 x 15/85) + 2.500.000

$=$ Rp.17.703.639+2.500.000

$=$ Rp.20.203.639

Dari hasil perhitungan di atas, secara sempel dapat dikatakan bahwa dengan adanya penerapan metode gross up jumlah penghasilan bruto karyawan tersebut dalam satu tahun pajak sebesar Rp.189.864.259,- dan Pajak penghasilan terutang karyawan tersebut sebesar Rp.20.203.639,- dalam satu tahun, besarnya PPh terutang tersebut sama dengan tunjangan pajak yang diberikan, dengan menggunakan metode ini perusahaan dapat membebankan biaya tunjangan pajak sebagai deductible expenses, sehingga dapat mengurangi PPh badan perusahaan yang bersangkutan. Dengan catatan, selama di dukung adanya perjurnalan biaya tunjangan pajak di dalam pembukuan wajib pajak serta juga tercantum dalam slip gaji karyawan.

Dari data yang telah diolah dapat dilihat untuk tunjangan Pajak dan $\mathrm{PPh}$ terutang besarnya sama, dengan menggunakan metode ini Pajak Penghasilan PPh pasal 21 lebih besar dibandingkan dengan metode yang lainnya, dan dapat disimpulkan dalam tabel 2 untuk jumlah PPh pasal 21 terutang selama tahun 2011 sampai dengan tahun 2013 yaitu sebagai berikut:

Tabel 2

Jumlah PPh Pasal 21 terutang method Gross Up

\begin{tabular}{|c|c|}
\hline Tahun & PPh Pasal 21 \\
\hline 2011 & Rp. 119.481.780 \\
\hline 2012 & Rp.154.972.180 \\
\hline 2013 & Rp.149.191.120 \\
\hline
\end{tabular}

Sumber : Data diolah sendiri

Pada tahun $2011 \mathrm{PPh}$ terutang jika menggunakan metode gross up sebesar Rp.119.481.780,-, sedangkan pada tahun 2012 PPh terutang 
mengalami kenaikan sebesar Rp.35.490.400,- dari tahun sebelumnya dikarenakan adanya kenaikan gaji dan tunjangan-tunjangan lainnya pada setiap karyawan, dan pada akhir tahun 2013 gaji dan tunjangan lainnya mengalami kenaikkan, tetapi untuk Pajak Penghasilan pasal 21 terhutang malah sebaliknya artinya mengalami penurunan sebesar Rp.5.781.060,- dari tahun sebelumnya juga, dikarenakan keluar peraturan perpajakan yang berlaku mulai 1 Januari 2013 yaitu adanya kenaikan Penghasilan Tidak Kena Pajak (PTKP), sehingga banyak karyawan yang tidak kena PPh terutang.

\section{Beban Pajak Penghasilan Badan (Perusahaan)}

\section{a. Perhitungan Beban Pajak Penghasilan Badan dengan method Net}

Dalam hal ini perusahaan harus melakukan rekonsiliasi untuk memperoleh beban pajak penghasilan perusahaan dengan cara koreksi positif dan koreksi negative.

\section{1) Rekonsiliasi Fiskal Laporan Laba Rugi method Net Basic}

Berikut ini adalah laporan laba rugi fiskal yang dibuat oleh PT. HI tahun 2011, tahun 2012, dan tahun 2013 diperoleh laporan laba rugi fiskal selama tiga tahun, dan dapat dilihat bahwa perusahaan melakukan koreksi positif dan negative tersebut objek yang dikoreksi setiap tahunnya sama, adapun unsur-unsur atau objek yang terkena koreksi fiskal adalah sebagai berikut:

a) Biaya Pajak Penghasilan Pasal 21

Pajak Penghasilan Pasal 21 yaitu pajak yang seharusnya menjadi tanggungan karyawan, dalam hal ini PT. Heavenish Indonesia untuk PPh Pasal 21 dibayar oleh perusahaan, tetapi tidak termasuk dalam tunjangan pajak sebagai tambahan penghasilan jadi terkena koreksi positif pada tahun 2011 Rp.104.244.910,- tahun 2012 Rp.135.398.720,- dan tahun 2013 Rp.128.074.650,-

b) Biaya Pajak (sanksi Perpajakan)

Menurut peraturan perpajakan sanksi administrasi berupa 
bunga, denda, dan kenaikan serta sanksi pidana berupa denda yang berkenaan dengan pelaksanaan perundang-undangan di bidang perpajakan merupakan biaya yang tidak dapat dikurangkan sebagai pengurang Penghasilan Kena Pajak, maka dikoreksi positif, dimana beban pajak pada tahun 2011 Rp.61.304.168,- tahun 2012 Rp.81.304.987,- dan tahun 2013 Rp.64.837.599,-

c) Biaya Sumbangan

Biaya sumbangan tersebut yang menjadi beban perusahaan atau pengurang Laporan komersial, tetapi bukan pengurang penghasilan bruto buat laporan keuangan fiskal dan tidak dapat dikurangkan untuk menghitung Penghasilan Kena Pajak, maka harus dikoreksi fiskal positif, dimana biaya sumbangan pada tahun 2011 Rp.17.986.000,- pada tahun 2012 Rp.28.659.000,dan pada tahun 2013 Rp.35.901.000,-

d) Biaya Entertaiment

Biaya entertaiment ini berkaitan dengan pemberian kenikmatan kepada pihak ke tiga. Dalam hal ini biaya entertaiment dapat dibiayakan ke laporan keuangan fiskal jika disertai dengan bukti yang jelas dan dibuatkan daftar nominatif, tetapi perusahaan ini selama ini tidak memiliki bukti tersebut, jadi semua biaya tidak dapat dibiayakan dan dikoreksi fiskal positif, dimana tahun 2011 Rp.34.587.990, pada tahun 2012 Rp.46.693.787, dan tahun 2013 Rp.54.711.721,-

e) Biaya Lain-lain

Biaya lain-lain ini tidak dapat dibiayakan dalam laporan keuangan fiskal, karena tidak ada bukti pendukung dan keterangan yang jelas biaya tersebut untuk apa saja, makanya harus dikoreksi positif,dimana biaya pada tahun 2011 Rp.71.811.540,- pada tahun 2012 Rp.79.008.968, dan tahun 2013 Rp.86.827.815,- 
f) Pendapatan Jasa Giro

Pendapatan jasa giro merupakan penghasilan yang sudah dikenakan Pajak Penghasilan Final, maka atas penghasilan tersebut harus dikoreksi fiskal negatif, dimana pada tahun 2011 Rp.9.678.996, pada tahun 2012 Rp.15.589.769, dan pada tahun 2013 Rp.6.027.850,-

g) Biaya Pajak Jasa Giro

Pajak yang sudah dipotong oleh pihak bank merupakan Pajak Penghasilan bersifat Final, jadi atas biaya pajak jasa giro tersebut dikoreks positif dimana tahun 2011 Rp.193.580,- pada tahun 2012 Rp.311.795,- dan tahun 2013 Rp.386.239,--

\section{2) Perhitungan pajak terhutang dengan method net basic}

Setelah mengetahui berapa besar koreksi positif dan negatif dan telah didapat laporan keuangan fiskal rekap Pajak Penghasilan badan PT. HI selama tahun 2011-2013. Dimana setiap tahun mengalami kenaikan, pada tahun 2011 Pajak Penghasilan Perusahaan Rp.370.006.388,- pada tahun 2012 mengalami kenaikan sebesar Rp.85.502.314 dari tahun sebelumnya, begitu juga pada tahun 2013 mengalami kenaikan Rp.79.678.478 dari tahun 2012, untuk Pajak Penghasilan badan yaitu :

Tabel 3

Jumlah Pajak Penghasilan Badan Method Net

\begin{tabular}{|c|c|}
\hline Tahun & Jumlah \\
\hline 2011 & Rp. 371.006.388 \\
\hline 2012 & Rp.456.508.702 \\
\hline 2013 & Rp.536.187.180 \\
\hline
\end{tabular}

Sumber: Data diolah sendiri

\section{3) Laporan Laba Rugi Fiskal Method Net Basic}

Berikut ini adalah kondisi laporan keuangan fiskal perusahaan, artinya kondisi laporan keuangan perusahaan setelah dikurangi dengan Pajak Penghasilan Badan yang harus dibayar dan dapat dilihat laba yang diperoleh perusahaan selama tiga tahun tersebut 
dimana pada tahun 2011 sebesar Rp.1.053.933.148,-- pada tahun 2012 Rp.1.232.084.716,- dan pada tahun 2013 laba yang diperoleh perusahaan sebesar Rp.1.439.072.907,- untuk mengetahui dari mana laba tersebut diperoleh.

\section{b. Perhitungan Beban Pajak Penghasilan Badan dengan method Gross Up}

\section{1) Rekonsiliasi Fiskal dan perhitungan Pajak Penghasilan Badan dengan method Gross Up}

Dari data yang telah diolah dapat dilihat bahwa koreksi positif dan negatif untuk tahun 2011 telah diketahui, mengenai penjelasan objek Pajak yang dikoreksi positif dan negatif tersebut sama penjelasnya dengan metode net basic yang telah diuraikan sebelumnya, namun yang membedakan hal ini adalah di beban Pajak Penghasilan Pasal 21, dimana metode gross Up PPh pasl 21 ditunjang ole perusahaan, jadi setelah diketahuinya koreksi positif dan negatif tersebut maka harus melakukan perhitungan Pajak Penghasilan Badan untuk mengetahui seberapa besar beban pajak Perusahaan jika menggunakan metode gross up. Berikut perhitungan Pajak Penghasilan PPh Badan Perusahaan tahun 2011:

Dari perhitungan tersebut PT. HI menggunakan perhitungan dengan menggunakan Pasal 31E, dimana pada tahun 2011 jika menggunakan metode gross Up. Rp.345.013.192,- . tahun 2012 telah diketahui, kemudian setelah diketahui koreksi positif dan negatif tersebut maka harus melakukan perhitungan Pajak Penghasilan Badan untuk mengetahui seberapa besar beban pajak Perusahaan jika menggunakan metode gross up. Untuk tahun 2012 ini beban Pajak perusahaan Rp.421.903.532, mengalami kenaikan dari tahun 2011 dengan selisih Rp.76.890.340,-. Untuk tahun 2013 Pajak Penghasilan badan PT. Heavenish Indonesia dengan metode gross up adalah Rp.498.533.177,- dimana mengalami kenaikan lagi dari tahun sebelumnya selisih diperoleh Rp.76.629.645,- 


\section{2) Laporan Laba rugi Fiskal Method Gross Up}

Setelah peneliti melakukan koreksi fiskal dan perhitungan Pajak Penghasilan badan selama tahun 2011 sampai dengan 2013 tersebut diatas, kondisi laporan keuangan fiskal perusahaan dengan menggunakan metode gross up setelah adanya pengurangan Pajak Penghasilan,

3. Pengaruh Perbandingan penerapan method net basic dan method gross up terhadap Beban Pajak Penghasilan Badan

Untuk mengetahui perbandingan beban pajak perusahaan dimana jika menerapkan method net dan method gross up dalam hal ini bisa mempengaruhi seberapa besar beban pajak penghasilan perusahaan, dalam hal ini perusahaan melakukan perencanaan pajak selain memperhatikan kesejahtraan karyawan harus memperhatikan dampak bagi perusahaan terutama mengenai Pajak penghasilan Pasal 21, Perusahaan ini menggunakan method net basic dalam menanggung seluruh PPh Pasal 21 karyawan, sebagaimana telah dibahas sebelumnya perusahaan harus mengeluarkan dana untuk menanggung Pajak karyawannya yang setiap tahunnya berubah, dimana biaya Pajak Penghasilan yang dikeluarkan oleh perusahaan dikoreksi fiscal positif. Sedangkan untuk metode gross up Pajak Penghasilan Pasal 21 merupakan tunjangan Pajak karyawan dimana tunjangan pajak tesebut tidak dikoreksi fiscal oleh perusahaan, berikut dibawah ini tabel 4untuk perbandingan PPh Pasal 21 method gross up dan method net basic perusahaan selama tahun 2011 sampai dengan 2013:

Tabel 4

Perbandingan PPh Pasal 21 Method gross up dan net basic

\begin{tabular}{|c|c|c|c|}
\hline \multirow{2}{*}{ Tahun } & \multicolumn{3}{|c|}{ PPH 21 } \\
\cline { 2 - 4 } & Metode Gross Up & Metode Net Basic & Selisih \\
\hline 2011 & 119.481 .780 & 104.244 .910 & 15.236 .870 \\
\hline 2012 & 154.972 .180 & 135.398 .720 & 19.573 .460 \\
\hline 2013 & 149.191 .120 & 128.074 .650 & 21.116 .470 \\
\hline
\end{tabular}

Sumber : Data diolah sendri

Dari tabel diatas dapat dilihat bahwa dengan menggunakan metode 
net basic pph terutang perusahaan lebih kecil dan jika menggunakan metode gross up $\mathrm{PPh}$ terutang perusahaan lebih besar, dimana selisih diperoleh setiap tahunnya meningkat, tetapi hal ini ada pengaruhnya terhadap beban pajak yang dikeluarkan perusahaan dan laba yang diperoleh perusahaan sebelum adanya Pajak penghasilan, berikut perbandingan sebagai berikut:

Tabel 5

Perbandingan laba sebelum pajak metode gross up dan net basic

\begin{tabular}{|c|c|c|c|}
\hline \multirow{2}{*}{ Tahun } & \multicolumn{3}{|c|}{ Laba Rugi sblm Pjk } \\
\cline { 2 - 4 } & Metode Gross Up & Metode Net Basic & SELISIH \\
\hline 2011 & 1.409 .702 .666 & 1.424 .939 .536 & $(15.236 .870)$ \\
\hline 2012 & 1.669 .021 .970 & 1.688 .593 .418 & $(19.571 .448)$ \\
\hline 2013 & 1.954 .147 .616 & 1.975 .260 .086 & $(21.112 .470)$ \\
\hline \multicolumn{2}{|c|}{ Sumber :Data diolah sendiri }
\end{tabular}

Tabel 6

Perbandingan PPh badan Metode gross up dan net basic

\begin{tabular}{|c|c|c|c|}
\hline \multirow{2}{*}{ Tahun } & \multicolumn{3}{|c|}{ PPh Badan } \\
\cline { 2 - 4 } & $\begin{array}{c}\text { Metode } \\
\text { Gross Up }\end{array}$ & $\begin{array}{c}\text { Metode Net } \\
\text { Basic }\end{array}$ & SELISIH \\
\hline 2011 & 345.013 .192 & 371.006 .388 & $(25.993 .196)$ \\
\hline 2012 & 421.903 .532 & 456.508 .702 & $(34.605 .170)$ \\
\hline 2013 & 498.533 .177 & 536.187 .180 & $(37.654 .003)$ \\
\hline
\end{tabular}

Tabel 7

Perbandingan laba sebelum pajak metode gross up dan net basic

\begin{tabular}{|c|c|c|c|}
\hline \multirow{2}{*}{ Tahun } & \multicolumn{3}{|c|}{ Laba Setelah Pajak } \\
\cline { 2 - 4 } & $\begin{array}{c}\text { Metode Gross } \\
\text { Up }\end{array}$ & $\begin{array}{c}\text { Metode Net } \\
\text { Basic }\end{array}$ & SELISIH \\
\hline 2011 & 1.064 .689 .474 & 1.053 .933 .148 & 10.756 .326 \\
\hline 2012 & 1.247 .118 .437 & 1.232 .084 .716 & 15.033 .722 \\
\hline 2013 & 1.455 .614 .439 & 1.439 .072 .907 & 16.541 .533 \\
\hline \multicolumn{4}{|l|}{ Sumber :Data diolah sendiri } \\
\hline
\end{tabular}

Berdasarkan tabel diatas dapat dilihat perbandingan penerapan metode gross up dan net basic, sangat berpengaruh pada beban pajak penghasilan, 
dengan metode net basic PPh Badan lebih besar dan laba sebelum pajak pun besar, tetapi dengan metode gross up ini perusahaan memperoleh laba lebih kecil daripada menggunakan metode net basic , dari sisi laporan keuangan komersil menggunakan metode net basic lebih efektif, dan metode gross up lebih merugikan dengan selisih laba yang diperoleh pada tahun 2011 Rp.15.236.870,- pada tahun 2012 Rp.19.571.448, dan pada tahun 2013 sebesar Rp.21.112.470,-. Dalam sisi perpajakan (sisi fiskal) lebih efektif menggunakan metode gross up walapun laba dalam posisi komersil lebih kecil hal ini dapat menghemat beban pajak penghasilan perusahaan dimana pada tahun 2011 sebesar Rp.25.993.196,- pada tahun 2012 Rp.34.605.170,- dan pada tahun 2013 sebesar Rp.37.654.003,- tetapi untuk perolehan laba setelah pajak metode gross up lebih besar dari metode net basic untuk selisih dapat dilihat dari tabel 8 dimana selisih diperoleh tahun 2011 sebesar Rp.10.756.326,- pada tahun Rp.15.033.722,dan tahun 2013 sebesar Rp.16.541.533,- karena metode gross up ini biaya Pajak Penghasilan Pasal 21 tidak dikoreksi fiskal, disisi lain jika perusahaan menggunakan metode gross up perusahaan dapat menghemat sebesar selisih PPh badan tersebut dan perusahaan dapat mengangsur PPh terutang (Pasal 25) setiap bulanya lebih kecil daripada menggunakan metode net basic.

Tabel 8

Rekap Pajak Penghasilan Badan Method Gross Up

\begin{tabular}{|c|c|}
\hline Tahun & Jumlah \\
\hline 2011 & Rp. 345.013 .192 \\
\hline 2012 & Rp. 421.903 .532 \\
\hline 2013 & Rp. 498.533 .177 \\
\hline
\end{tabular}

Sumber: Data diolah sendiri

\section{c. Penerapan method Gross Up dalam perhitungan pajak penghasilan}

\section{Pasal 21}

Pada tahun 2011 PPh terutang jika menggunakan metode gross up sebesar Rp.119.481.780,-, sedangkan pada tahun 2012 PPh terutang mengalami 
kenaikan sebesar Rp.35.490.400,- dari tahun sebelumnya dikarenakan adanya kenaikan gaji dan tunjangan-tunjangan lainnya pada setiap karyawan, dan pada akhir tahun 2013 gaji dan tunjangan lainnya mengalami kenaikkan, tetapi untuk Pajak Penghasilan pasal 21 terhutang malah sebaliknya artinya mengalami penurunan sebesar Rp.5.781.060,dari tahun sebelumnya juga, dikarenakan keluar peraturan perpajakan yang berlaku mulai 1 Januari 2013 yaitu adanya kenaikan Penghasilan Tidak Kena Pajak (PTKP), sehingga banyak karyawan yang tidak kena $\mathrm{PPh}$ terutang.

\section{Pengaruh Perbandingan penerapan method net basic dan method} gross up terhadap Beban Pajak Penghasilan Badan

Untuk mengetahui perbandingan beban pajak perusahaan dimana jika menerapkan method net dan method gross up dalam hal ini bisa mempengaruhi seberapa besar beban pajak penghasilan perusahaan, dalam hal ini perusahaan melakukan perencanaan pajak selain memperhatikan kesejahtraan karyawan harus memperhatikan dampak bagi perusahaan terutama mengenai Pajak penghasilan Pasal 21, Perusahaan ini menggunakan method net basic dalam menanggung seluruh PPh Pasal 21 karyawan, sebagaimana telah dibahas sebelumnya perusahaan harus mengeluarkan dana untuk menanggung Pajak karyawannya yang setiap tahunnya berubah, dimana biaya Pajak Penghasilan yang dikeluarkan oleh perusahaan dikoreksi fiscal positif. Sedangkan untuk metode gross up Pajak Penghasilan Pasal 21 merupakan tunjangan Pajak karyawan dimana tunjangan pajak tesebut tidak dikoreksi fiscal oleh perusahaan, menggunakan metode net basic pph terutang perusahaan lebih kecil dan jika menggunakan metode gross up $\mathrm{PPh}$ terutang perusahaan lebih besar, dimana selisih diperoleh setiap tahunnya meningkat, tetapi hal ini ada pengaruhnya terhadap beban pajak yang dikeluarkan perusahaan dan laba yang diperoleh perusahaan sebelum adanya Pajak penghasilan. Berdasarkan data yang diolah dapat dilihat perbandingan penerapan metode gross up dan net basic, sangat berpengaruh pada beban pajak 
penghasilan, dengan metode net basic PPh Badan lebih besar dan laba sebelum pajak pun besar, tetapi dengan metode gross up ini perusahaan memperoleh laba lebih kecil daripada menggunakan metode net basic , dari sisi laporan keuangan komersil menggunakan metode net basic lebih efektif, dan metode gross up lebih merugikan dengan selisih laba yang diperoleh pada tahun 2011 Rp.15.236.870,- pada tahun 2012 Rp.19.571.448, dan pada tahun 2013 sebesar Rp.21.112.470,-. Dalam sisi perpajakan (sisi fiskal) lebih efektif menggunakan metode gross up walapun laba dalam posisi komersil lebih kecil hal ini dapat menghemat beban pajak penghasilan perusahaan dimana pada tahun 2011 sebesar Rp.25.993.196,-- pada tahun 2012 Rp.34.605.170,- dan pada tahun 2013 sebesar Rp.37.654.003,- tetapi untuk perolehan laba setelah pajak metode gross up lebih besar dari metode net basic untuk selisih dapat dilihat dari tabel 4.32 dimana selisih diperoleh tahun 2011 sebesar Rp.10.756.326,pada tahun Rp.15.033.722,- dan tahun 2013 sebesar Rp.16.541.533,karena metode gross up ini biaya Pajak Penghasilan Pasal 21 tidak dikoreksi fiskal, disisi lain jika perusahaan menggunakan metode gross up perusahaan dapat menghemat sebesar selisih PPh badan tersebut dan perusahaan dapat mengangsur PPh terutang (Pasal 25) setiap bulanya lebih kecil daripada menggunakan metode net basic.

\section{SIMPULAN}

Dengan menggunakan metode net basic dalam perhitungan Pajak Penghasilan Pasal 21, Pajak yang terutang selama tiga tahun berturut-turut dimana pada tahun 2011 sebesar Rp.104.244.910, pada tahun 2012 sebesar Rp.135.398.720,- dan tahun 2013 Rp.128.074.650, sedangkan jika menggunakan metode gross up, Pajak Penghasilan Pasal 21 terutang lebih besar daripada menggunakan metode net basic, dimana PPh terutang tahun 2011 Rp.119.481.780,- pada tahun 2012 Rp.154.972.180, dan tahun 2013 Rp.149.191.120,- dimana dalam hal penerapan metode net basic dan gross up ini terdapat selisih pada tahun 2011 Rp.15.236.870,- tahun 2012 Rp.19.517.460,- dan tahun 2013 Rp.21.116.470. 
Dalam perhitungan mengenai beban pajak penghasilan badan, jika perhitungan tersebut menggunakan metode net basic maka diperoleh beban pajak penghasilan badan, dimana pada tahun 2011 Rp.371.006.308, pada tahun 2012 Rp.456.508.702. dan pada tahun 2013 Rp.536.187.180,- dan jika perhitungan menggunakan metode gross up maka diperoleh beban pajak penghasilan badan selama tiga tahun, dimana pada tahun 2011 Rp.345.508.702,- pada tahun 2012 Rp.421.903.532,- dan pada tahun 2013 Rp.498.533.171,-.

Berdasarkan analisis perbandingan penerapan antara metode net basic dan gross up hal ini berpengaruh sekali pada beban pajak penghasilan, sebagaimana dapat di lihat pada point 2 di atas mengenai beban pajak penghasilan badan, terdapat selisih/perbedaan tersebut disebabkan adanya koreksi fiskal dalam peraturan perpajakan, dimana perusahaan menggunakan metode net basic dalam perhitungan PPh Pasal 21, PPh terutang tersebut dikoreksi fiskal positif (tidak dapat dibebankan dalam laporan keuangan fiskal), sedangakan jiak menggunakan metode gross up Pajak terutang tersebut tidak dilakukan koreksi fiskal dan dapat dibebankan dalam laporan fiskal. Jadi selisih Beban pajak penghasilan tersebut, bagi perusahaan lebih dapat menguntungkan menggunakan metode gross up dimana dapat menghemat beban Pajak Penghasilan atau menghasilkan efisiensi terhadap Pajak penghasilan Badan selama tiga tahun yaitu pada tahun 2011 sebesar Rp. 25.993.196, pada tahun 2012 sebesar Rp. 34.605.170, dan pada tahun 2013 sebesar Rp. 37.654.003,-

\section{REFERENSI}

Indonesia Tax Review. 2009. Akuntansi PPh Pasal 21 Tahun 2009: Volume II/Edisi 14/2009.

Indonesia Tax Review. 2004. Gross Up PPh Pasal 21 Tidak Harus Konsisten: Volume IV/Edisi 05/2004.

Mardiasmo. 2011. Perpajakan, Edisi Revisi. Yogyakarta: Andi Offset.

Muljono Djoko. 2010. Panduan Brevet Pajak Pajak Penghasilan, Edisi 1. Yogyakarta: Andi. 
Muljono Djoko. 2009. Tax Planning Menyiasati Pajak dengan Kebijakan. Yogyakarta: Andi.

Radianto, Wirawan. 2010. Memahami Pajak Penghasilan Dalam Sehari: Konsep \& Aplikasi Praktis. Yogyakarta: Graha Ilmu.

Resmi, Siti. 2009. Perpajakan: Teori Dan Kasus Buku Satu Edisi Lima. Jakarta Salemba Empat.

Salim, Agus, Hidayat Taufik, Susanto, Eko. 2014. Buku panduan pajak lengkap 2014. Jakarta: Educipta solusi.

Salim,Peter, Salim Yenni. 2002. Kamus Besar Bahasa Indonesia.

Sari, Diana, Perpajakan Kosep, Teori, dan Aplikasi Pajak Penghasilan, Mitra Wacana Media, Jakarta, 2014.

Suandy, Erly. Perencanaan Pajak Edisi 4, Salemba Empat, Jakarta, 2009.

Sugiyono, Metode Penelitian Kualitatif kuantitatif dan R\&D, Alfabeta, Bandung, , 2011.

Sugiyono, Statistika untuk Penelitian, Alfabeta, Bandung, 2010.

Sumarsan, Thomas, Perpajakan Indonesia, Indeks, Jakarta, 2010.

Team Tax Centre, Pajak Terapan Brevet A-B, Edisi 2011, PT. Bina Fiskal Indonesia, Tangerang, 2011.

Undang-Undang Republik Indonesia Nomor 38 Tahun 2009, Ketentuan Umum Dan Tata Cara Perpajakan, 2010.

Peraturan Direktorat Jenderal Pajak Nomor: Per-31/Pj/2009 tentang Pedoman Teknis Tata Cara Pemotongan, Penyetoran, Dan Pelaporan Pajak Penghasilan Pasal 21 Dan/Atau Pajak Penghasilan Pasal 26 Sehubungan Dengan Pekerjaan, Jasa, Dan Kegiatan Orang Pribadi.

Peraturan Derjen Pajak No, 31/PJ/2008.

Peraturan Diren Pajak No.94/PJ/2009.

Waluyo. "Perpajakan Indonesia”, Edisi 9, Salemba Empat, Jakarta, 2010.

www.Pajak.go.Id

www.pelayananpajakpusat.go.id 